ranger now convalescent was in the same hospital with him for sixteen hours before a cholera hospital could be established outside the camp and fort.

2. It is believed that all these men were of intemperate habits. The ranger who is dead, it is known, generated the disease within him by a fit of intoxication.

3. This disease having appeared among the rangers and on this island, all in commission are called upon to exert themselves to the utmost to stop the spread of the calamity.

4. Sobriety, cleanliness of person, cleanliness of camp and quarters, together with care in the preparation of the men's messes, are the grand preventatives. Nu neglect under these heads will be overlooked or tolerated.

5. In addition to the foregoing the senior surgeon present recommends the use of llannel shirts, flannel drawers, and woolen stockings; but the commanding general, who has seen much of disease, knows that it is intemperance, which in the present state of the atmosphere, generates and spreads the calamity, and that when once spread good and temperate men are likely to take the infection.

6. He therefore peremptorily commands that every soldier or ranger that shall be found drunk or sensibly intoxicated after the publication of this order be compelled, as soon as his strength will permit, to dig a grave at a suitable burying place, large onough for his own reception, as such grave cannot fail soon to be wanted for the drunken man himself, or some drunken companion.

7. This order is given, as well to serve for the punishment of drunkness, as to spare good temperate men the labor of digging graves for their worthless companions.

8. The sanitary regulations now in force respecting communications between the camp near the mouth of Rock river and other camps and posts in the neighborhood are revoked. Colonel Eustis, however, whose troops are perfectly free from cholera, will report to the commanding general whether he believes it for the safety of his command that these regulations should be renewed.

By order of Major-General ScotT, P. H. GarT, Assistant Adjutant-General.

\title{
A PRO-SLAVERY LETTER BY JOHN C. CALHOUN.
}

Persons born since the great civil war have little idea of the deep feeling which existed for so many years throughout this country, relating to human slavery. Two points especially gave rise to the bitterest acrimony. 
These were the claims of the southern people of the right to take their slaves with them into the territories-and. hold them there as at home-a right denied by a large majority at the north; and the enforcement of the fugitive slave law, which made every man "a negro catcher," if his aid were required by a United States Marshal. It was the first of these disturbing questions which brought about conditions of actual war in the Territory of Kansas in the later fifties. About the time Iowa was admitted into the Union there were a few slaves in Dubuque and Des Moines counties, brought north doubtless upon the theory that they could be held in bondage "under the Constitution." The southern champion of this doctrine was John C. Calhoun, the great statesman of South Carolina, who not only represented his State several times in the United States Senate, but spoke for the entire south upon the slavery question and the "compromises of the Constitution." He was ready even as early as 1832 to go into rebellion on the issue of the right of a State to nullify the laws of Congress, involving of course the right of a State to secede from the Union whenever it chose so to do. The tariff was the particular bone of contention at that time-the protective system being distasteful to South Carolina. The firmness of President Andrew Jackson "put down the rebellion" for the time being. He is said to have threatened, among other things, that he would appoint that born soldier, General Henry Dodge, of Wisconsin, United States Marshal of South Carolina, under whose iron rule there would have been no doubt of the enforcement of the Federal laws. South Carolina gave up the contest then, but the rebellion broke out in larger proportions upon her soil in 1861, resulting in the greatest civil war known to history. The preposterous claims of the Old South upon the slavery question have seldom been more tersely and clearly set forth than in the following hitherto unpublished letter of Mr. Cal- 
houn to Honorable Laurel Summers of Iowa, now in the State Historical Collections:

For' HuL, (S. C.), 16th Nov. 184 S.

DeAr SIR: You are right. Consolidation is shaking this government to its center, and will overthrow it, unless we abandon a loose and latitudinous construction of the constitution, and return to the old and rigid construction, which brought the republican party into power.

You ask me: What right has Congress to compromise the subject of slavery? I answer none at all. That it is a subject that does not fall within its province, except to pass such acts as may aid in carrying out the compromises of the Constitution in reference to it, including the delivering of fugitive slaves, and the apportionment of direct taxes. and of representition in the House of Representatives, and to secure the just equality of the eitizens in all places where it has exclusive jurisdiction, and in reference to all subjects falling within its jurisdiction. It can make no discrimination between the citizens of one state and another, on account of their local institutions or from any other cause.

But while I hold that Congress has no power to pass a compromise line or to prohibit the citizens to emigrate with their slaves into the territories of the United States, I at the same time hold, the inhabitants of the territories have no such right, until they are authorized to form a State and to enter the Union as one of its members. The sovereignty over the territories is ixclusively in the people of the several States, composing the Union, in their federal character, as such, and it is the greatest absurdity to suppose, that the inhabitants of a territory before they are authorized to form a State, can perform an act that involves the high exercise of sovereign power.

With respect, I am, etc.,

I A UREL SumMrer, EsQ.

J. C. Calhoun.

\section{CHIEF JUSTICE CHARLES MASON.}

As stated elsewhere a superb oil portrait of this illus. trious early Iowan, from the easel of Geo. H. Yewell, N. A., was presented to the State-the Supreme Court receiving it for permanent preservation in its chamberson the 22d day of May last. The remarks of Judges Wright and Kinne contain fitting tributes to Judge Mason's character as a soldier, scholar, citizen, scientist and jurist, placing on record interesting and valuable informa- 
Copyright of Annals of Iowa is the property of State of Iowa, by \& through the State Historical Society of Iowa and its content may not be copied or emailed to multiple sites or posted to a listserv without the copyright holder's express written permission. However, users may print, download, or email articles for individual use. 